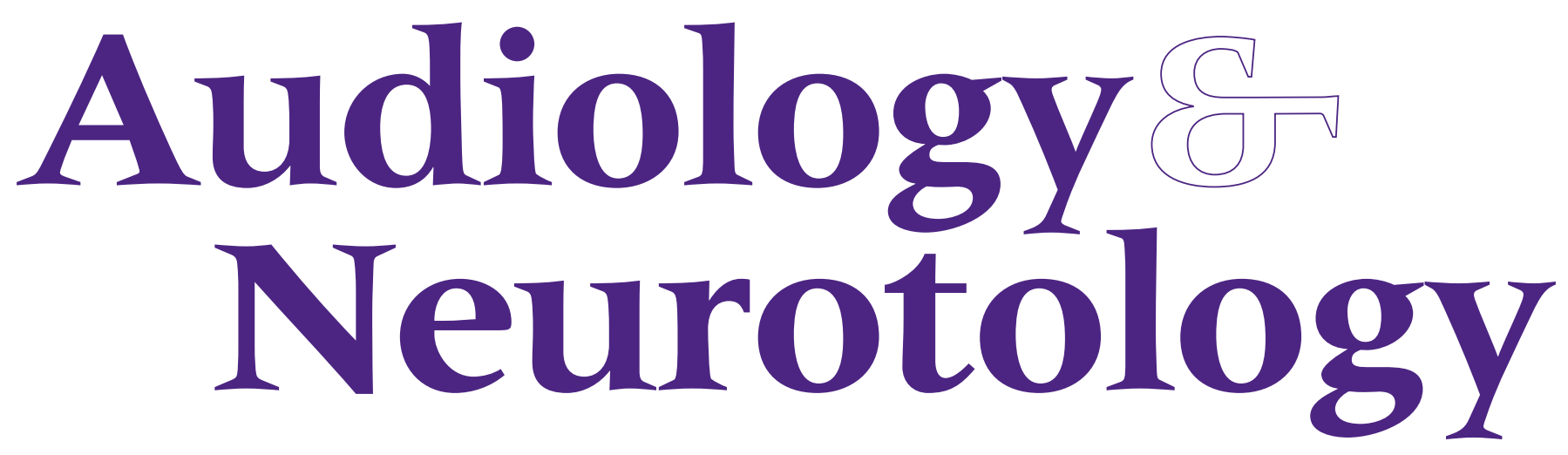

The Science of Hearing and Balance

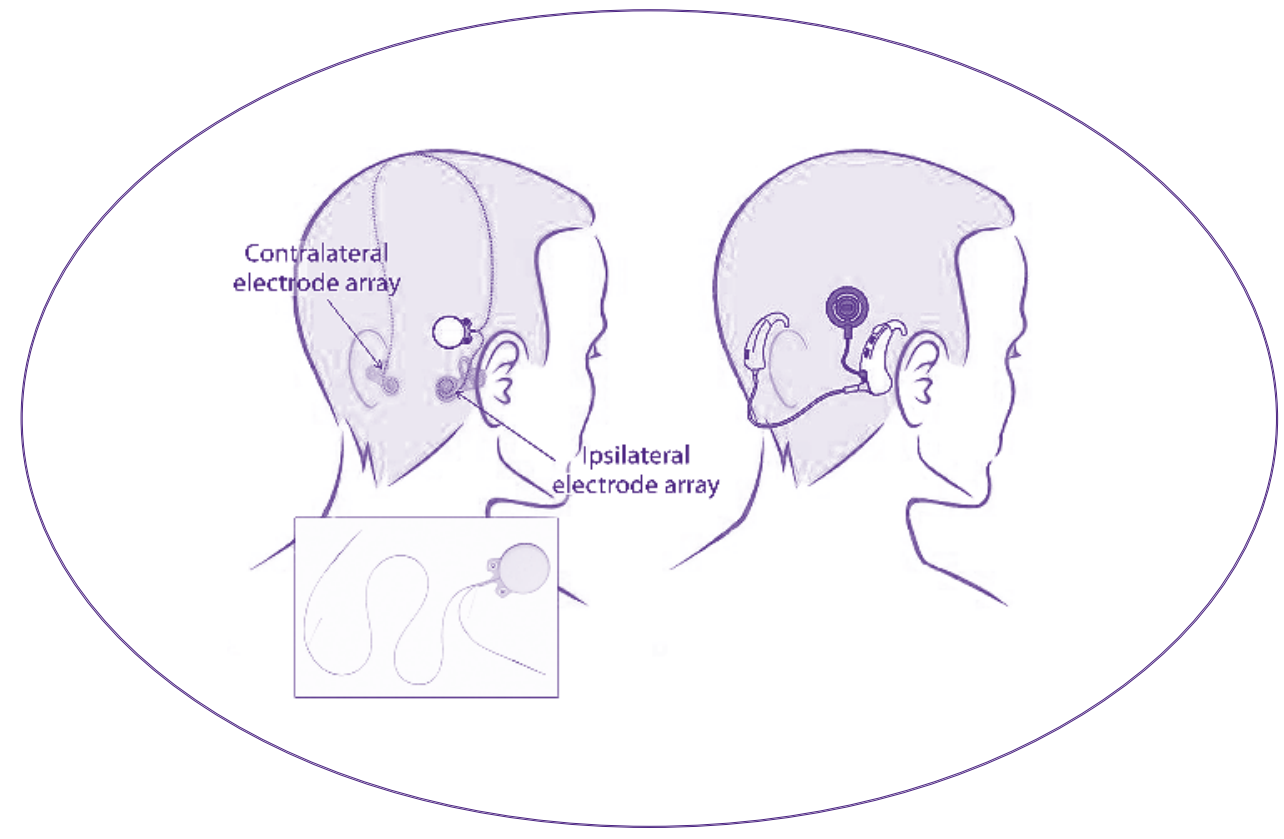

S. Karger

Medical and Scientific Publishers Basel - Freiburg · Paris .

London - New York .

New Delhi · Bangkok · Beijing ·

Tokyo - Kuala Lumpur ·

Singapore $\cdot$ Sydney 


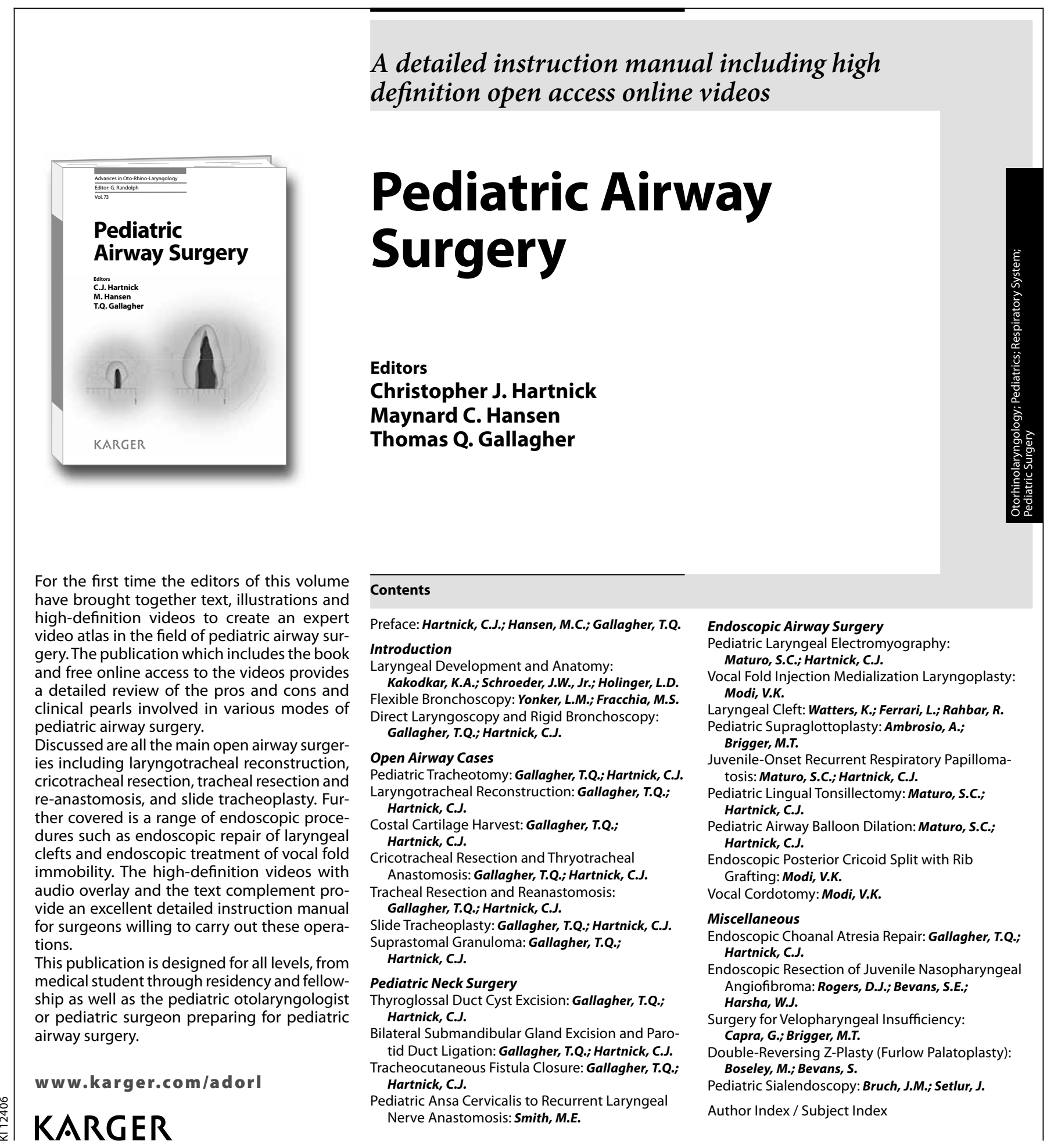

\section{Advances in Oto-Rhino-Laryngology,} Vol. 73

Series Editor: Randolph, G. (Boston, Mass.) ISSN 0065-3071 / e-ISSN 1662-2847

Pediatric Airway Surgery

Editors: Hartnick, C.J.; Hansen, M.C.; (Boston, Mass.) Gallagher, T.Q. (Portsmouth, Va.)

VIII + 158 p., 130 fig., 89 in color, 1 tab., hard cover + online supplementary material, 2012

CHF 198.- / EUR 165.- / USD 233.00

CHF 198.- / EUR 165.- /
Prices subject to change

EUR price for Germany, USD price for USA only

ISBN 978-3-8055-9931-3

e-ISBN 978-3-8055-9932-0

\section{$\rightarrow$ Please send: __ copy/ies}

Postage and handling free with prepayment

E

- Payment:

Please charge to my credit card

- $\quad \square$ American Express $\quad \square$ Diners

• $\square$ MasterCard $\square$ Visa

- Card No.

(

ర Exp.date:

CVV/CVC

(3 digits in the signature field on the back of Visa and MasterCard)

$\square$ Check enclosed $\quad \square$ Please bill me

Orders may be placed with any bookshop, subscription agency, directly with the publisher or through a Karger distributor.
Fax: +41 613061234

S. Karger AG, P.O. Box, CH-4009 Basel (Switzerland)

E-Mail orders@karger.ch,www.karger.com

Name/Address: 


\section{Audiology Neurotology}

The Science of Hearing and Balance

Journal founded 1996 by Manfried Hoke (Editor-in-Chief 1996-2004)

\section{Editor-in-Chief}

Jeffrey P. Harris, San Diego, Calif.

\section{Section Editors}

Paul Avan, Clermont-Ferrand

(Audiology)

Malou Hultcrantz, Stockholm

(Hearing genetics)

John P. Carey, Baltimore

(Basic and clinical research of the

vestibular system)

Joseph Nadol, Boston

(Clinical otology/neurotology)

Allen F. Ryan, La Jolla

(Molecular otology, molecular

genetics, hair cell and neural

regeneration)

Jochen Schacht, Ann Arbor

(Inner ear biochemistry,

pharmacology, ototoxicity and

protection)

Christoph E. Schreiner, San Francisco

(Central auditory processing)

\section{Official Organ of}

Deutsche Gesellschaft für Audiologie e.V.

\section{Editorial Board}

Maurizio Barbara, Rome

Olivier Bertrand, Bron

F. Owen Black, Portland

Thomas Brandt, München

Barbara Canlon, Stockholm

John P. Carey, Baltimore

Douglas A. Cotanche, Boston

Cor W.R.J. Cremers, Nijmegen

Norbert Dillier, Zürich

Robert Dobie, Sacramento

Manuel Don, Los Angeles

Jill B. Firszt, St. Louis

Andrew Forge, London

Bernard Fraysse, Toulouse

Rick Friedman, Los Angeles

Bruce J. Gantz, Iowa City

Pablo Gil-Loyzaga, Madrid

Anthony W. Gummer, Tübingen

James W. Hall III, Gainesville

Joseph W. Hall III, Chapel Hill

Michael Halmagyi, Camperdown

Rudolf Häusler, Bern

Vicente Honrubia, Los Angeles

Gary D. Housley, Auckland

Karl-Bernd Hüttenbrink, Köln

Pawel J. Jastreboff, Atlanta

Margaret A. Kenna, Boston

Philippe P. Lefebvre, Liège

Bernd Lütkenhöner, Münster

Linda L. Luxon, London

Geoffrey A. Manley, Oldenburg
Alessandro Martini, Padova Jennifer R. Melcher, Boston Saumil N. Merchant, Boston Brian C.J. Moore, Cambridge David R. Moore, Nottingham Cynthia C. Morton, Boston Donata Oertel, Madison Kaoru Ogawa, Tokyo Stephen J. O'Leary, Parkville Alan R. Palmer, Nottingham Lorne S. Parnes, London, Ont. Jean-Luc Puel, Montpellier Ramesh Rajan, Monash Yehoash Raphael, Ann Arbor J. Thomas Roland, New York John J. Rosowski, Boston Rudolf Rübsamen, Leipzig Mario A. Ruggero, Evanston Leonard P. Rybak, Springfield Richard J. Salvi, Buffalo Robert V. Shannon, Los Angeles Guido F. Smoorenburg,

Besse sur Issole Haim Sohmer, Jerusalem Olivier Sterkers, Clichy Istvan Sziklai, Debrecen Peter R. Thorne, Auckland Shin-ichi Usami, Matsumoto P. Ashley Wackym, Portland Tatsuya Yamasoba, Tokyo Fan-Gang Zeng, Irvine
Printed in Switzerland on acid-free and non-aging paper (ISO 9706) by Reinhardt Druck, Basel
Appears bimonthly: 1 volume per year (6 issues) 


\section{Audiology Neurotology}

\section{Submission}

Manuscripts written in English should be submitted using the online submission website at:

\section{www.karger.com/aud}

or as e-mail attachment (the preferred word-processing package is MS-Word) to the Editorial Office:

\author{
aud@karger.ch \\ Jeffrey P. Harris, MD, Ph.D \\ S. Karger AG \\ Editorial Office 'Audiology and Neurotology' \\ P.O. Box \\ CH-4009 Basel (Switzerland)
}

Please include the names, postal and e-mail addresses of four experts in the appropriate area of research either from the editorial board or elsewhere. Selected scientist(s) will be invited to act as referee(s) by the editors.

For any further details please contact Audiology \& Neurotology's Editorial Office:

$$
\begin{aligned}
& \text { Tel. +41 } 613061358 \\
& \text { Fax +41 } 613061434 \\
& \text { E-Mail aud@karger.ch }
\end{aligned}
$$

\section{Conditions}

All manuscripts are subject to editorial review. Manuscripts are received with the explicit understanding that they are not under simultaneous consideration or have been rejected by any other publication. Accepted papers become the permanent property of Audiology and Neurotology' and may not be reproduced by any means, in whole or in part, without the written consent of the publisher. It is the author's responsibility to obtain permission to reproduce illustrations, tables, etc. from other publications.

Research involving live human and animal subjects must have been approved by the author's institutional review board. All clinical investigations must have been conducted according to the principles expressed in the Declaration of Helsinki.

Contributors should know that one of the criteria considered in reviewing manuscripts is the humane and proper treatment of animals. The editors realize that the use of anesthetics, analgesics, and tranquilizers would defeat the purpose of some experiments. However, the use of painful or otherwise noxious stimuli must be carefully and thoroughly justified. Papers that do not meet these criteria will not be accepted for publication.

\section{Types of Papers}

Papers of the following types are considered for publication:

- Original Paper

- Editorial

- Review or Mini Review

- Invited Review

\section{Reviews and Mini Reviews}

Most (Mini) Reviews are submitted upon invitation. However, the editors are open to unsolicited (Mini) Reviews. Authors planning to submit a (Mini) Review are requested to contact the Editorial Office with an outline of the intended contribution. All (Mini) Reviews are subject to peer review.

\section{Conflicts of Interest}

Authors are required to disclose any sponsorship or funding arrangements relating to their research and all authors should disclose any possible conflicts of interest. Conflict of interest statements will be published at the end of the article.

\section{Arrangement}

Title page: The first page of each paper should indicate the title, authors' names, institute where the work was conducted, and a short title for use as running head.

Full address: The exact postal address of the corresponding author complete with postal code must be given at the bottom of the title page. Please also supply phone and fax numbers, as well as e-mail address.

Key words: For indexing purposes, a list of 3-10 key words in English is essential.

Abstract: Each paper needs an abstract in English of up to 10 lines.

\section{Footnotes: Avoid footnotes.}

Tables and illustrations: Tables and illustrations (both numbered in Arabic numerals) should be stored in seperate files. Tables require a heading and figures a legend, also in separate files. Labels of illustrations should begin with an upper-case letter and be centered; units should be in parentheses. For graphs containing coordinates (plots) please conform to the sample figure shown in the Guidelines for Authors at: www.karger. com/aud_Guidelines.

Due to technical reasons, figures with a screen background should not be submitted. When possible, group several illustrations in one block for reproduction (max. size $180 \times 223 \mathrm{~mm}$ ). B/w half-tone and color illustrations must have a final resolution of $300 \mathrm{dpi}$ after scaling, line drawings one of 800-1,200 dpi.

Color illustrations

Online edition: Color illustrations are reproduced free of charge. In the print version, the illustrations are reproduced in black and white. Please avoid referring to the colors in the text and figure legends.

Print edition: Up to 6 color illustrations per page can be integrated within the text at CHF 800.- per page.

Terminology: Authors are advised to use the terminology recommended by the ISO-IEC, Nomina Anatomica and WHO list of approved names for drugs.

Abbreviations: Their use should be limited and they should be explained when first mentioned.

Audiograms: All audiograms must be plotted according to ISO standards.

References: Identify references [in square brackets] in the text by naming the authors and the year. 1 author: [Forsten, 1990]; 2 authors: [Geddes and Rølla, 1988]; 3 and more authors: [Hallgren et al., 1992]. Material submitted for publication but not yet accepted should be noted as 'unpublished data' and may not be included in the reference list. The list of references should include only those publications cited in the text. Arrange the reference list in strict alphabetical order according to the examples given below. The authors' surnames followed by their initials should be given, and each name should be separated by a comma. Preferably, please cite all authors. For papers by the same authors, listing should be according to the year; for papers by the same authors published in the same year, use the letters a, b, c, etc. directly (no space) connected to the year. For journal abbreviations, please use the Index Medicus system. For details see www.icmje.org.

Examples

(a) Papers published in periodicals: Chatel J-M, Bernard $\mathrm{H}$, Orson $\mathrm{FM}$ : Isolation and characterization of two complete Ara h 2 isoforms cDNA. Int Arch Allergy Immunol 2003;131:14-18.

(b) Papers published only with DOI numbers:

Theoharides TC, Boucher W, Spear K: Serum interleukin-6 reflects disease severity and osteoporosis in mastocytosis patients. Int Arch Allergy Immunol DOI: $10.1159 / 000063858$.

(c) Monographs: Matthews DE, Farewell VT: Using and Understanding Medical Statistics, ed 3, revised. Basel, Karger, 1996.

(d) Edited books: Hone SW, Smith RJH: Understanding inner ear physiology at the molecular level; in Cremers Cor WRJ, Smith RJH (eds): Genetic Hearing Impairment. Adv Otorhinolaryngol. Basel, Karger, 2002, vol 61, pp 1-10.

\section{Digital Object Identifier (DOI)}

S. Karger Publishers supports DOIs as unique identifiers for articles. A DOI number will be printed on the title page of each article. DOIs can be useful in the future for identifying and citing articles published online without volume or issue information. More information can be found at www.doi.org.

\section{Author's Choice ${ }^{\mathrm{TM}}$}

Karger's Author's Choice ${ }^{\mathrm{TM}}$ service broadens the reach of your article and gives all users worldwide free and full access for reading, downloading and printing at www.Karger.com. The option is available for a onetime fee of CHF 3000.-, which is a permissible cost in grant allocation. More information can be found at www.karger.com/authors_choice.

\section{Supplementary Material}

Supplementary material is restricted to additional data that are not necessary for the scientific integrity and conclusions of the paper. Please note that all supplementary files will undergo editorial review and should be submitted together with the original manuscript. The Editors reserve the right to limit the scope and length of the supplementary material. Supplementary material must meet production quality standards for Web publication without the need for any modification or editing. In general, supplementary files should not exceed $10 \mathrm{MB}$ in size. All figures and tables should have titles and legends and all files should be supplied separately and named clearly. Acceptable files and formats are: Word or PDF files, Excel spreadsheets (only if the data cannot be converted properly to a PDF file), and video files (.mov, .avi, .mpeg).

\section{NIH-Funded Research}

The U.S. National Institutes of Health (NIH) mandates under the NIH Public Access Policy that final, peer-reviewed manuscripts appear in its digital database within 12 months of the official publication date. As a service to authors, Karger submits the final version of your article on your behalf to PubMed Central. For those se lecting our premium Author's Choice ${ }^{\mathrm{TM}}$ service, we will send your article immediately upon publishing, accelerating the accessibility of your work without the usual

\section{KARGER}

Fax +4161306 1234 E-Mail karger@karger.ch www.karger.com
(C) 2012 S. Karger AG, Basel 
embargo. More details on NIH's Public Access Policy is available at http://publicaccess.nih.gov/FAQ.htm\#al

\section{Self-Archiving}

Karger permits authors to archive their pre-prints (i.e. pre-refereeing) or post-prints (i.e. final draft post-refereeing) on their personal or institution's servers, provided the following conditions are met: Articles may not be used for commercial purposes, must be linked to the publisher's version, and must acknowledge the publisher's copyright. Authors selecting Karger's Author's Choice ${ }^{\mathrm{TM}}$ feature, however, are also permitted to archive the final, published version of their article, which includes copyediting and design improvements as well as citation links.

\section{Page Charges}

There are no page charges for papers of 4 or fewer printed pages (including tables, illustrations and references). A charge of CHF 650.- will be levied for each page in excess of the allotted 4 printed pages. The allotted size of a paper is equal to approx. 10 manuscript pages (double-spaced, including tables, illustrations and references).

\section{Proofs}

Unless indicated otherwise, proofs are sent to the firstnamed author and should be returned with the least possible delay. Alterations made in proofs, other than the correction of printer's errors, are charged to the author. No page proofs are supplied.

\section{Reprints}

Order forms and a price list are sent with the proofs. Orders submitted after the issue is printed are subject to considerably higher prices.

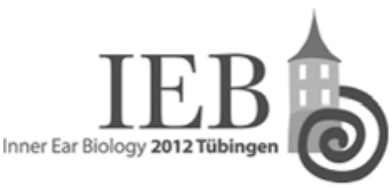

\section{9th Workshop on Inner Ear Biology}

30 September - 02 October 2012

and

Symposium

The Inner Ear in Translational Research:

Closing the Gap toward Causal Treatment

29 September 2012

Invited symposium presentations

Free oral presentations

Poster sessions

Temporal bone and $\mathrm{Cl}$ preparation

European CME Accreditation in process
Organisers

Anthony W. Gummer, Hubert Löwenheim

Marlies Knipper, Hans-Peter Zenner

University of Tübingen, Dept. Otolaryngology

Elfriede-Aulhorn-Str. 5, 72076 Tübingen, Germany

anthony.gummer@uni-tuebingen.de

http://www.innerearbiology.de

\section{KARGER}

Fax +4161306 1234

E-Mail karger@karger.ch

www.karger.com
(C) 2012 S. Karger AG, Basel

The Guidelines for Authors are available at:

www.karger.com/aud_Guidelines 


\section{Audiology Neurotology}

ISSN Print Edition: 1420-3030

ISSN Online Edition: 1421-9700

Journal Homepage: www.karger.com/aud

Publication Data: 'Audiology and Neurotology' is pears in 2012.

Copyright: $\odot 2012$ S. Karger AG, Basel (Switzerland). All rights reserved. No part of this publication may be translated into other languages, reproduced or utilized in any form or by any means, electronic or mechanical, including photocopying, recording, microcopying, or by any information storage and retrieval system, without permission in writing from the publisher or, in the case of photocopying, direct payment of a specified fee to the Copyright Clearance Center.

Disclaimer: The statements, opinions and data contained in this publication are solely those of the individual authors and contributors and not of the publisher and the editor(s). The appearance of advertisements in the journal is not a warranty, endorsement, or approval of the products or services advertised or of their effectiveness, quality or safety. The publisher and the editor(s) disclaim responsibility for any injury to persons or property resulting from any ideas, methods, instructions or products referred to in the content or advertisements. published 6 times a year. Volume 17 with 6 issues ap-
Subscription Rates: Subscriptions run for a full calendar year. Prices are given per year. Personal subscription:

Print or Online

CHF 541.-

EUR 433.-

USD 525.00

Print+Online combined CHF 589.-

EUR 471.-

USD 572.00

postage and handling (added to print and print+online)

CHF 40.80 Europe, CHF 60.00 Overseas

EUR 31.20

USD 56.40

Institutional subscription:

Print or Online

Print+Online combined

CHF 1545.-

EUR 1236.-

USD 1500.00

EUR 1360.-

postage and handling (added to print and print+online)

CHF 51.- Europe, CHF 75.- Overseas

EUR 39.-

USD 70.50

Airmail surcharge: CHF 51.- / USD 48.00

Discount subscription prices:

Members of ISA;

Deutsche Gesellschaft für Audiologie e.V.;

Italian Society of Audiology;

ARO please ask for special rates.
CHF 1700.-
Back Volumes and Single Issues: Information on availability and prices of single print issues and print or electronic back volumes can be obtained from Cus-

Bibliographic Indices: This journal is regularly listed in bibliographic services, including Current Contents ${ }^{\circledR}$ and PubMed/MEDLINE.

Photocopying: This journal has been registered with the Copyright Clearance Center (CCC), as indicated by the code appearing on the first page of each article. For readers in the US, this code signals consent for copying of articles for personal or internal use, or for the personal or internal use of specific clients, provided that the stated fee is paid per copy directly to

Copyright Clearance Center Inc.

222 Rosewood Drive

Danvers, MA 01923 (USA)

A copy of the first page of the article must accompany payment. Consent does not extend to copying for general distribution, for promotion, for creating new works, or for resale. In these cases, specific written permission must be obtained from the copyright owner,

S. Karger AG, P.O. Box

CH-4009 Basel (Switzerland). tomer Service at service@karger.ch.
Subscription Orders:

Orders can be placed at agencies, bookstores, directly with the Publisher

\section{S. Karger AG}

Medical and Scientific Publishers

P.O. Box

CH-4009 Basel

Switzerland

(for courier services only:

CH-4055 Basel)

$\mathrm{t}:+41613061111$

f: +41613061234

e: karger@karger.ch

w: www.karger.com
Allschwilerstrasse 10 or further Karger offices

or representatives:

Germany

S. Karger GmbH

Postfach

79095 Freiburg

Deutschland

(Hausadresse: Wilhelmstrasse 20A

79098 Freiburg)

t: +49761452070

f: +497614520714

w: www.karger.de

Japan

Karger Japan, Inc.

Shiba Daimon Asahi Bldg. 2F

1-2-23 Shiba Daimon

Minato-ku

Tokyo 105-0012

Japan

t: +81364356242

f: +81364356244

e: publisher@karger.jp

w: www.karger.jp e: information@karger.de

Change of Address:

Both old and new address should be sent

to the subscription source.
USA

S. Karger Publishers, Inc.

P.O. Box 529

Unionville, CT 06085

USA

Toll free: +1 8008285479

t: +18606757834

f: +18606757302

e: karger@snet.net

France

Librairie Médi-Sciences Sarl

36, bd de Latour-Maubourg

75007 Paris

France

t: $+33(0) 145514258$

f: $+33(0) 145560780$

f: +33(0) 145560780

e: librairie@medi-sciences.

Gulf Council Countries, Iran,

Middle East, North Africa, Turkey

Trans Middle East International

Distribution Co. Ltd.

KaSha

134 Queen Rania Al Abdullah Street

Jordan Trade Center Bldg. 3rd Floor

P.O. Box 2376

Amman 11953

Jordan

t: +96265153467

f: +96265153472

e: info@kasha.cc

w: www.KaShaonline.com
26 West Avon Road
South East Asia, China and Taiwan Karger Regional Office (Malaysia)

CEO Suite Kuala Lumpur

Quill 7, 27th Floor

Jalan Stesen Sentral 5

KL Sentral

Kuala Lumpur 50470

Malaysia

t: +60327766803

f: +60327766999

e: service@karger.cn; r.chew@karger.cn

\section{Karger China}

10th Floor, Twin Towers (East)

B12 Jianguomenwai Avenue

Beijing 100022

China

t: +861051235033

f: +861051235122

e: service@karger.cn; r.chew@karger.cn

w: www.karger.cn

Medscience India

Plot No. 17, Yusuf Sarai Market

B.L. Glass Building, 2nd Floor

Sri Aurobindo Marg

New Delhi 110016

India

t: +911146029633

f: +911146029634

c: +919891052128

e: medsci.india@gmail.com
India, Bangladesh, Sri Lanka

\section{KARGER}

Fax +41 613061234

E-Mail karger@karger.ch

www.karger.com
(C) 2012 S. Karger AG, Basel

The Journal Home Page is available at:

www.karger.com/aud 


\section{Contents}

See the journal website for contents

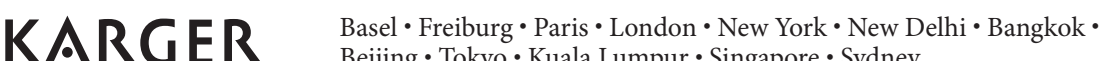
Beijing $\cdot$ Tokyo $\cdot$ Kuala Lumpur $\cdot$ Singapore $\cdot$ Sydney 


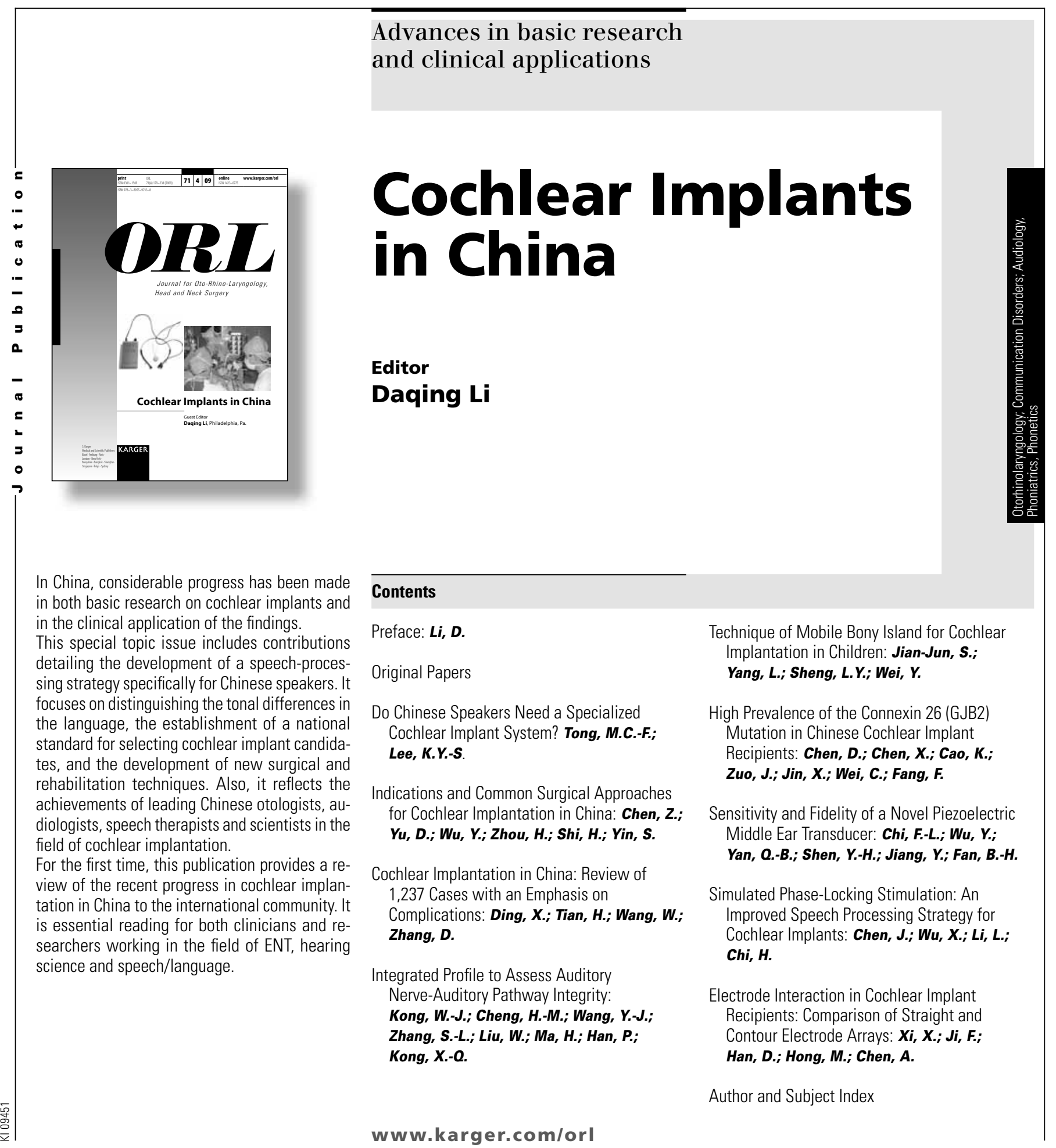

ORL

Editor: O'Malley, B.W. (Philadelphia, Pa.)

ISSN 0301-1569 / e-ISSN 1423-0275

Special issue: Vol. 71, No. 4 (2009)

Included in subscription

Cochlear Implants in China

Editor: Li, D (Philadelphia, Pa.)

60 p., 20 fig., 3 in color, 13 tab., soft cover, 2009

CHF 29.- / EUR 24.- / USD 34.00

Prices subject to change

EUR price for Germany, USD price for USA only

ISBN 978-3-8055-9233-8

e-ISBN 978-3-8055-9234-5

\section{KARGER}

$\rightarrow$ Please send:___ copy/ies

Postage and handling free with prepayment

E Payment:

- Please charge to my credit card

- $\square$ American Express $\square$ Diners $\square$ Eurocard

ᄂ $\square$ MasterCard $\quad \square$ Visa

- Card No.

o

- Exp. date

-

- CVV/CVC

(3 digits in the signature field on the back of Visa and MasterCard)

\section{$\square$ Check enclosed $\quad \square$ Please bill me}

Orders may be placed with any bookshop, subscription agency, directly with the publisher or through a Karger distributor.

\section{Fax: +4161306 1234}

S. Karger AG, P.0. Box, CH-4009 Basel (Switzerland) E-Mail orders@karger.ch, www.karger.com

Name/Address:

Date:

Signature: 


\section{Audiology Neurotology}

Original Papers

207 Tuning Characteristics of Ocular and Cervical Vestibular Evoked Myogenic Potentials in Intact and Dehiscent Ears

Taylor, R.L.; Bradshaw, A.P.; Halmagyi, G.M.; Welgampola, M.S. (Sydney, N.S.W.)

219 Clinical Follow-Up and Histopathology of the Temporal Bones in Nathalie Syndrome de Heer, A.-M.R. (Nijmegen); Merchant, S.N. (Boston, Mass.); Kammeraad, J.A.E.; Cruysberg, J.R.M.; Huygen, P.L.M. (Nijmegen); Cremers, C.W.R.J. (Boston, Mass.)

228 Comprehensive Analysis of Head-Shaking Nystagmus in Patients with Vestibular Neuritis

Lee, Y.J.; Shin, J.E.; Park, M.S.; Kim, J.M.; Na, B.R.; Kim, C.-H.; Park, H.J. (Seoul)

235 Pharmaceutical Countermeasures Have Opposite Effects on the Utricles and Semicircular Canals in Man

Weerts, A.P.; De Meyer, G.; Pauwels, G.; Vanspauwen, R. (Edegem); Dornhoffer, J.L. (Little Rock, Ark.); Van de Heyning, P.H.; Wuyts, F.L. (Edegem)

243 Surgical Management of Tympanojugular Paragangliomas with Intradural Extension, with a Proposed Revision of the Fisch Classification

Sivalingam, S. (Kuala Lumpur); Konishi, M. (Moriguchi); Shin, S.-H. (Seoul); Lope Ahmed, R.A.R. (Kuantan); Piazza, P. (Parma); Sanna, M. (Piacenza/Chieti)

256 Speech Performance and Sound Localization Abilities in Neurelec Digisonic ${ }^{\circledR}$ SP Binaural Cochlear Implant Users

Verhaert, N. (Lyon/Leuven); Lazard, D.S. (Clichy); Gnansia, D. (Vallauris); Bébéar, J.-P. (Bordeaux); Romanet, P. (Dijon); Meyer, B. (Clichy/Lyon); Péan, V.; Mollard, D. (Vallauris); Truy, E. (Lyon)

267 Esteem 2 Middle Ear Implant: Our Experience

Gerard, J.M.; Thill, M.P.; Chantrain, G.; Gersdorff, M.; Deggouj, N. (Brussels) 